monuments that had been laid flat was a reasonable and proportionate method of ensuring that the local authority discharged its continuing obligation in respect of those monuments. The appeal was allowed only to the limited extent set out above. [RA]

doi:10.1017/So956618Xo9002154

\title{
Archdeacon of Northampton v Davies
}

Disciplinary Tribunal, Diocese of Peterborough, November 2008 Inappropriate sexual behaviour - drunkenness - prohibition

The complainant complained that the respondent, the Reverend Teresa Davies, had acted in a manner unbecoming a clerk in holy orders. The first allegation centred on the respondent's alleged sexual activities, including 'the casual exchange of sexual partners' and her and her husband's advertising on 'swingers' websites. The second allegation was that the respondent was under the influence of alcohol at four separate church services. The complaint was upheld and the respondent, who had already resigned her preferment, was prohibited from the exercise of the functions of her orders for twelve years and placed on the Archbishops' List maintained under section 38 of the Clergy Discipline Measure 2003. [WA]

A transcript of the tribunal's determination may be found at http://www.ecclaw.co.uk/ clergydiscipline/davies1.pdf and of the imposition of penalty at http://www.ecclaw. co.uk/clergydiscipline/davies2.pdf

\section{Archdeacon of Colchester v Gair}

Disciplinary Tribunal, Diocese of Chelmsford, November 2008 Adultery - impartiality of tribunal

The Archdeacon brought a complaint that the respondent, the Rector of Debden with Wimbish and Thunderly, had conducted an inappropriate affair with a parishioner, Mrs X, whose husband had turned to him for support when the marriage was in difficulty. The tribunal found, on the balance of probability, that the relationship was of a sexual nature and therefore conduct unbecoming. He was prohibited from the exercise of the functions of his order for seven years from the date of the determination. There were several preliminary rulings in this case. The respondent sought to ensure that both clerical members of the 